\title{
Establishment of Cell Suspension Culture and Plant Regeneration in Abrus precatorius L., a Rare Medicinal Plant
}

\author{
Mohammad Serajur RAHMAN ${ }^{1}$, Mohammad Abdul Bari MIAH ${ }^{2}$, Mohammad Shahadat \\ HOSSAIN ${ }^{1}$, Ahmad Humayan KABIR ${ }^{3}$, Mohammad Motiur RAHMAN ${ }^{1,2 *}$ \\ ${ }^{1}$ University of Rajshahi, Department of Genetic Engineering and Biotechnology, Rajshahi 6205, Bangladesh \\ ${ }^{2}$ University of Rajshabi, Institute of Biological Sciences, Rajshahi 6205, Bangladesh \\ ${ }^{3}$ Flinders University, School of Biological Sciences, Bedford Park, SA 5042, Australia; motiur7@yahoo.com (*corresponding author)
}

\begin{abstract}
A new protocol has been developed for cell culture and in vitro regeneration of Abrusprecatorius that holds enormous potentiality for preparation of medicines. In vitro grown calli were cultured in Murashige and Skoog (MS) liquid media in agitated condition fortified with $0.5 \mathrm{mg} / 1$ 6-Benzylaminopurine. Growth curve of cells revealed that the cells continued to grow until 12 days of culture and got the highest peak from day 6-8. Isolated cell was found to produce highest $8.2 \%$ calli when suspended on MS medium supplemented with 0.5 $\mathrm{mg} / \mathrm{l}$ 6-Benzylaminopurine and $0.1 \mathrm{mg} / \mathrm{l}$ 1-Naphthaleneacetic acid. Callus derived from single cell produced highest number of embryo (25-28\%) cultured on MS medium fortified with $2.0 \mathrm{mg} / \mathrm{l}$ 6-Benzylaminopurine and $0.2 \mathrm{mg} / \mathrm{l}$ 1-Naphthaleneacetic acid. The bipolar embryos were selected and optimum shoot formation was recorded on MS medium supplemented with $2.0 \mathrm{mg} / 1$ 6-Benzylaminopurine and $0.1 \mathrm{mg} / \mathrm{l} 1$-Naphthaleneacetic acid. The optimum root induction was noticed in MS medium supplemented with $1.0 \mathrm{mg} / \mathrm{l}$ 3-Indolebutyric acid. Rooted plantlets were successfully transferred to potting soil and acclimatized to outdoor conditions.
\end{abstract}

Keywords: cell culture, callus induction, growth curve medical plant

\section{Introduction}

Many higher plants are major sources of natural products used as pharmaceuticals, agrochemicals, flavor and fragrance ingredients, food additives, and pesticides ( $\mathrm{Ba}-$ landrin and Klocke, 1988; Goossens et al., 2003). The search for new plant derived chemicals should thus be a priority in current and future efforts towards sustainable conservation and rational utilization of biodiversity. In the search for alternatives to production of desirable medicinal compounds from plants, biotechnological approaches, specifically, plant tissue cultures, are found to have potential as a supplement to traditional agriculture in the industrial production of bioactive plant metabolites (Rao and Ravishankar, 2002; Vanisree and Hsin-Sheng, 2004). Cell suspension culture systems could be used for large scale culturing of plant cells from which secondary metabolites could be extracted (Phillipson, 1990). The advantage of this method is that it can ultimately provide a continuous, reliable source of natural products. The possible use of plant cell cultures for the specific biotransformation of natural compounds have been demonstrated (Cheetham, 1995; Dixon et al., 2005; Elio et al., 2004; Facchini et al., 2004; Grotewold, 2004; Jung and Stephanopoulos, 2004; Krings and Berger, 1998; Ralley et al., 2004; Ravishankar and Rao, 2004). Due to these advances, research in the area of tissue culture technology, for production of plant chemicals, has bloomed beyond expectations. Large-scale plant tissue culture have been found to be an attractive alternative approach to traditional methods of plantation as it offers a controlled supply of biochemicals, independent of plant availability (Hansen and Wright, 1999; Sajc et al., 2000).

Abrus precatorius has been used as an important medicinal plant for different remedies. Abrin is a well known toxic glycoprotein found in the seeds of Abrus precatorius (Winkel, 2004; Zhang, 2003). Even so, cell culture and in vitro plant regeneration were never investigated on Abrus precatorius. Under the present investigation abrin was the ultimate target compound to be extracted from Abrus precatorius cell culture. It is relatively difficult to regenerate the plant in tissue culture media but the plant profusely produced callus from any explants when given to a culture media supplemented with growth regulators. The aim of the present investigation is to establish an efficient protocol for cell culture and in vitro regeneration of Abrus precatorius in artificial medium, towards developing commercial venture for the production of valuable secondary metabolite, abrin.

\section{Materials and methods}

\section{Preparation of plant materials}

Mature seeds of Abrus precatorius L. were collected from a local forest and subjected for in vitro seed germination on MS (Murashige and Skoog, 1962) medium in 
the Laboratory of Biotechnology, Institute of Biological Sciences, University of Rajshahi, Bangladesh. Prior to inoculation, the collected seeds were surface sterilized with $\mathrm{HgCl}_{2}$ solution $(0.1 \% \mathrm{w} / \mathrm{v})$ for $4-6$ minutes. Thereafter, five washes were done, with sterile distilled water, to remove all traces of contaminated elements. The seeds germinated after 2 weeks of culture and the in vitro seedlings were used as source of explants.

\section{Callus induction}

Internodal and leaf segments were cut into segments $(0.5 \mathrm{~cm})$ and cultured on $8 \%(\mathrm{w} / \mathrm{v})$ agar solidified MS media, supplemented with growth regulators (1-Naphthaleneacetic acid and BAP) at different concentrations and combinations for callus induction. The $\mathrm{pH}$ of the medium was adjusted to 5.8 before autoclaving. All cultures were incubated at $25 \pm 2^{\circ} \mathrm{C}$ under $16 / 8$ hour photoperiod and relative humidity, maintained at $80 \%$. After 12 days, the isolated cells of the two explants were cultured on petridishes with liquid MS media, supplemented with different concentrations of BAP and combination with NAA and placed on growth chamber under light for callus induction. After 7 days of culture, the callus initiated from isolated single cells. Data were recorded on days of callus initiation, percentage of callus induction, color and texture of callus.

\section{Establishment of cell suspension culture}

In this investigation, the cells were isolated mechanically from the pre-established friable callus tissue by a needle and subsequent cell suspension culture by a pipette. To make cell suspension, the friable callus is transferred to liquid medium and the medium was continuously agitated by an orbital shaker. Due to continuous agitation, the cell clumps were broken and dispensed releasing single cells in the medium, resulting cell suspension. After filtration the cell suspension was centrifuged to collect the single cells from the suspension. This procedure is stated below step by step:

i) some conical flasks $(250 \mathrm{ml})$ were taken and $75 \mathrm{ml}$ of liquid MS medium was kept in each and autoclaved at $121^{\circ} \mathrm{C}$ temperature under 15 psi for 20 minutes;

ii) after autoclaving, the conical flasks, containing MS liquid media, they were taken in running laminar airflow and 4-5 pieces (about $1.5 \mathrm{~g}$ ) of pre-established friable greenish calli were transferred aseptically to the conical flasks having $75 \mathrm{ml}$ autoclaved liquid medium (without agar);

iii) the closures of the flasks were aseptically covered with aluminum foil and placed within the clamps of an orbital shaker moving at $200 \mathrm{rpm}$;

iv) after 7 days, the contents of each flask were poured through a sterilized sieve, having $500 \mu \mathrm{m}$ diameter pore and filtrate was collected in a big sterilized container. The filtrate contained only free cells that were ensured by mak- ing some slides with the filtrate, then photographs were taken for each of the slides.

\section{Cell suspension culture and cell growth}

Pre-established 10-12 days old friable callus containing rapid dividing cells were used as explants in this investigation. This calli were derived from internodal and leaf explants in liquid MS medium. In this investigation, to isolate the cells, most friable calli were transferred to agitating liquid medium where it was broken up and readily dispersed. The flask containing the culture was placed on the shaker at $200 \mathrm{rpm}$ in dark room and after 6-7 days, cells were isolated. Finally the single cells were filtrated using sieves $(100 \mu \mathrm{m})$. This time, the filtrate contained only free cells and to ensure single cell suspension culture the filtrate was taken on a slide for microscopic observation.

Free cells isolated from calli were grown as single cells under in vitro conditions, using MS media, supplemented with different concentrations and combinations of growth regulators, to observe the growth pattern of cells. Using the sterilized pipette, $5 \mathrm{ml}$ residue cells were re-suspended into the fresh liquid medium and dispensed the cells equally in several sterilized flasks of $250 \mathrm{ml}$ containing 70 $\mathrm{ml}$ liquid medium. The cell containing flasks were placed on shaker with $250 \mathrm{rpm}$, allowing the free cells to grow. To prepare a growth curve of dividing cells, the weights were taken 9 times, from each flask individually, and fresh weights of growing cells were weighted according to the filter paper method (Dicosmo and Misawa, 1995; Hossain et al., 2007).

\section{Formation of somatic embryos and plant regeneration}

Under the present study callus induced from single cells in liquid culture were rescued aseptically and cultured on MS semi solid medium under light to initiate embryo formation. Callus was sub-cultured individually in MS semi solid media (with agar) having singly BAP (6-Benzylaminopurine) and combined effect of BAP with NAA (1-Naphthaleneacetic acid) to observe the formation of somatic embryo. Number of embryos per callus was counted under stereomicroscope, from the beginning of embryogenesis, and average number of embryo was calculated. Embryo formation was observed during 8-10 days of culture. For shoot and root induction, embryos were transferred to MS semi solid medium containing different concentration and combinations of BAP, BAP, NAA, IBA and IBA (3-Indolebutyric acid) with NAA.

\section{Results}

\section{Isolation of single cell}

Cell culture in Abrus precatorius is a new venture in the country and it was necessary to find out the growth curve of the growing cells (Fig. 2). Plotting growth curve based on the cell growth is important to understand the 
88

optimum time period for cell division in liquid culture medium which is obligatory to maintain the cell culture in the laboratory (Fig. 1E, 1F). On this perspective, it has been started an experiment on cell division performance of Abrus precatorius plant in liquid culture medium under different time periods. And for this purpose, cell growth was observed and their weights were measured nine times, after each two days interval.

The cells continued to grow until 12 days and their gradual increase in weight with time was plotted in graph (Fig. 1G, 1H) resulted to form a growth carve. The peak period of cell growth was observed from $6^{\text {th }}$ day to $8^{\text {th }}$ day. The average cell weights were $0.0726 \mathrm{~g} / 5 \mathrm{ml}$ and 0.2943 $\mathrm{g} / 5 \mathrm{ml}$ in $6^{\text {th }}$ day and $12^{\text {th }}$ day respectively in leaf derived cells. On the other hand, the average cell weights were $0.0506 \mathrm{~g}$ and $0.2640 \mathrm{~g}$ in $6^{\text {th }}$ day and $12^{\text {th }}$ day respectively in case of internode derived cells. But the cell weight was ceased down after 12 days of culture in those two Abrus precatorius explants.

\section{Effect of BAP in liquid medium on callus induction}

Four concentrations of BAP $(0.1,0.2,0.5$ and $1.0 \mathrm{mg} / \mathrm{l})$ were used in MS media for callus induction from isolated single cells (Tab. 3 ). When the single cells of leaf derived callus were cultured on MS media, having $1.0 \mathrm{mg} / \mathrm{l} \mathrm{BAP,}$ $7.3 \%$ callus was induced within 8 days of culture and the result was creamy in color and friable in nature. $6.7 \% \mathrm{cal}$ lus was induced within 7 days of culture on MS media supplemented with $0.5 \mathrm{mg} / \mathrm{l} \mathrm{BAP}$. On the other hand, media with $1.0 \mathrm{mg} / \mathrm{l} \mathrm{BAP}$ gave $4.9 \%$ callus induction from the single cells of internodal derived callus within 24 days of culture. The callus was creamy in color and friable in nature (Fig. 1I, 1J).

\section{Effect of BAP and NAA in liquid medium on callus induction}

The highest $8.3 \%$ of callus induction was found from the leaf derived single cells in media, containing $0.5 \mathrm{mg} / \mathrm{l}$ BAP and $0.1 \mathrm{mg} / 1$ NAA within 6 days of culture. The callus was creamy in color and friable in nature (Fig. $1 \mathrm{~K}, 1 \mathrm{~L}$ ). When the single cells were cultured in MS media with 1.0 $\mathrm{mg} / \mathrm{l} \mathrm{BAP}$ along with $0.1 \mathrm{mg} / \mathrm{l} \mathrm{NAA}, 1.0 \mathrm{mg} / \mathrm{l} \mathrm{BAP}$ in addition to $0.2 \mathrm{mg} / \mathrm{l} \mathrm{NAA}, 2.0 \mathrm{mg} / \mathrm{l} \mathrm{BAP}$ plus $0.1 \mathrm{mg} / \mathrm{l}$ NAA and $2.0 \mathrm{mg} / 1 \mathrm{BAP}$ plus $0.2 \mathrm{mg} / \mathrm{l} \mathrm{NAA}$, the callus was white in color and friable. Moreover, $6 \%$ callus induction was found in $1.0 \mathrm{mg} / \mathrm{l} \mathrm{BAP}$ and $0.1 \mathrm{mg} / \mathrm{lNAA}$ within 10 days of culture. Maximum (94\%) callus induction took place on MS media fortified with $1.0 \mathrm{mg} / \mathrm{l} \mathrm{BAP}$ with 0.1 $\mathrm{mg} / \mathrm{l}$ NAA after two successive subcultures. In this investigation friable, creamy callus was developed from the cultured explants (Fig. 1 A-D).

The highest callus induction (5.3\%) was found in media supplemented with $0.5 \mathrm{mg} / \mathrm{lBAP}+0.1 \mathrm{mg} / \mathrm{l} \mathrm{NAA}$ within 22 days of culture from internode explants. The callus was creamy in color and friable in nature (Fig. 1M, 1N). White and hard callus was found in different media combination $(1.0 \mathrm{mg} / \mathrm{l} \mathrm{BAP}+0.1 \mathrm{mg} / \mathrm{l} \mathrm{NAA}, 1.0 \mathrm{mg} / \mathrm{l} \mathrm{BAP}+0.2 \mathrm{mg} / 1$ $\mathrm{NAA}, 2.0 \mathrm{mg} / \mathrm{l} \mathrm{BAP}+0.1 \mathrm{mg} / \mathrm{l} \mathrm{NAA}$ and $2.0 \mathrm{mg} / \mathrm{l} \mathrm{BAP}$ $+0.2 \mathrm{mg} / \mathrm{l} \mathrm{NAA})$. In this study, $3.3 \%$ of callus induction was found in media supplemented with $1.0 \mathrm{mg} / \mathrm{lBAP}$ and $0.1 \mathrm{mg} / 1 \mathrm{NAA}$ within 27 days of culture. In addition to it, $2 \%$ callus was induced in media having $2.0 \mathrm{mg} / \mathrm{l} \mathrm{BAP}$ and $0.2 \mathrm{mg} / \mathrm{l} \mathrm{NAA}$ within 35 days of culture. Results also revealed the best performance while treated with $0.5 \mathrm{mg} / \mathrm{l}$ BAP and $0.1 \mathrm{mg} / \mathrm{lNAA}$ in both the cases.

Tab. 1. Effect of growth regulators on callus induction from internodal and leaf explants

\begin{tabular}{|c|c|c|c|c|}
\hline $\begin{array}{c}\text { Growth regulators } \\
(\mathrm{mg} / \mathrm{l})\end{array}$ & $\begin{array}{c}\% \text { of explants induced } \\
\text { callus } \pm \text { STD }\end{array}$ & Degree of callusing & Colour of callus & Texture of callus \\
\hline \multicolumn{5}{|l|}{ BAP } \\
\hline 0.5 & $60 \pm 2.0$ & ++ & Creamy & Friable \\
\hline 1.0 & $70 \pm 2.2$ & +++ & Creamy & Friable \\
\hline 1.5 & $65 \pm 3.2$ & ++ & Creamy & Friable \\
\hline 2.0 & $60 \pm 1.6$ & ++ & Creamy & Friable \\
\hline 2.5 & $57 \pm 4.0$ & ++ & Creamy & Friable \\
\hline \multicolumn{5}{|l|}{$\mathrm{BAP}+\mathrm{NAA}$} \\
\hline $0.5+0.1$ & $60 \pm 3.1$ & ++ & Creamy & Friable \\
\hline $0.5+0.2$ & $68 \pm 1.9$ & ++ & Creamy & Friable \\
\hline $0.5+0.5$ & $74 \pm 1.2$ & +++ & Creamy & Friable \\
\hline $0.5+1.0$ & $80 \pm 5.3$ & +++ & Creamy & Friable \\
\hline $1.0+0.1$ & $94 \pm 1.3$ & +++ & Creamy & Friable \\
\hline $1.0+0.2$ & $90 \pm 2.0$ & +++ & Creamy & Friable \\
\hline $1.0+0.5$ & $80 \pm 3.7$ & +++ & Creamy & Friable \\
\hline $1.0+1.0$ & $80 \pm 3.4$ & +++ & Creamy & Friable \\
\hline $2.0+0.1$ & $80 \pm 1.4$ & +++ & Creamy & Friable \\
\hline $2.0+0.2$ & $80 \pm 0.5$ & +++ & Creamy & Friable \\
\hline $2.0+0.5$ & $74 \pm 6.2$ & +++ & Creamy & Friable \\
\hline $2.0+1.0$ & $67 \pm 2.5$ & ++ & Creamy & Friable \\
\hline
\end{tabular}

Values are the mean \pm standard deviation 

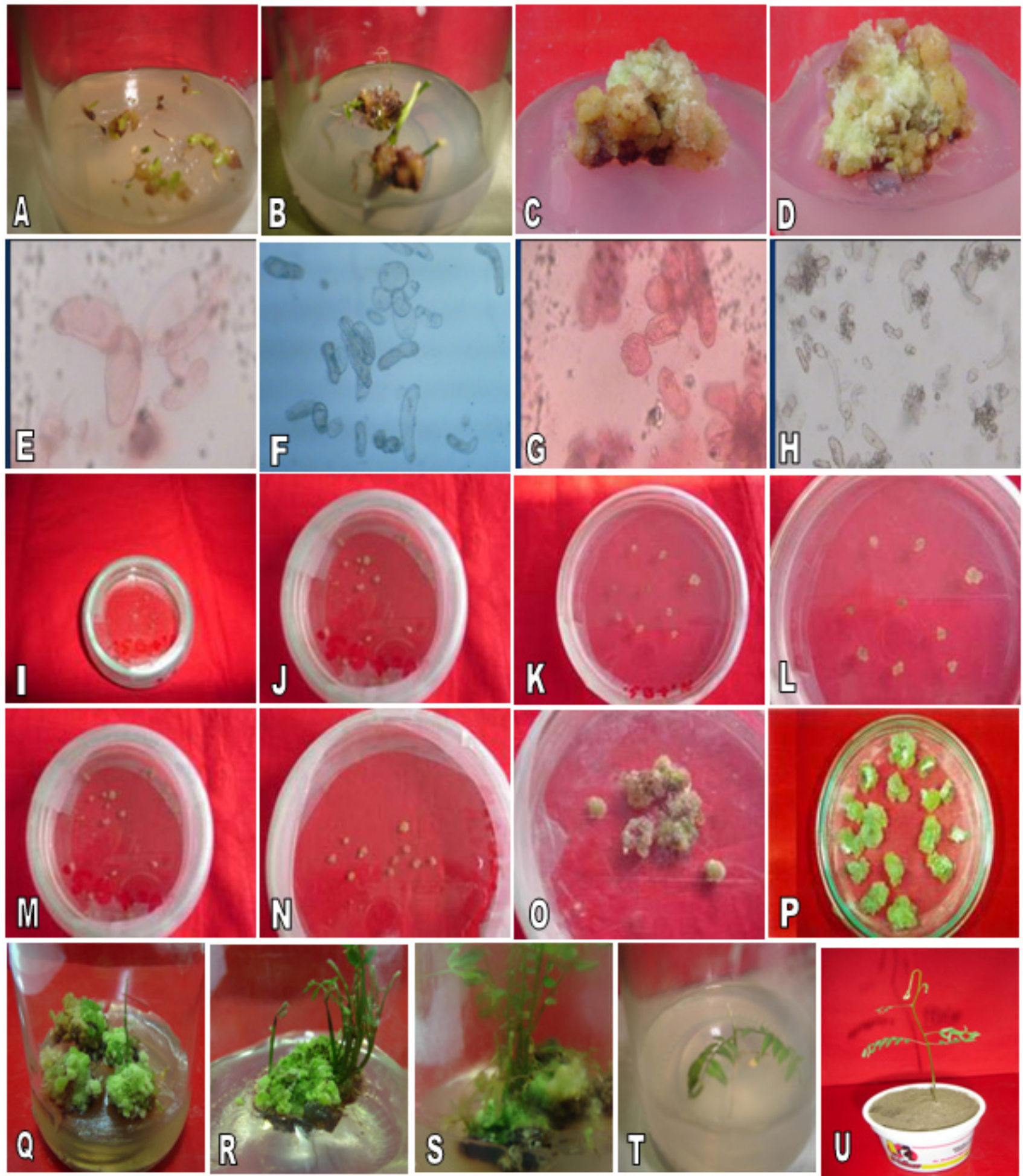

Fig. 1. Plant regeneration through cell culture. A: Callus induction of leaf explants; B: Callus induction of internodal explants; C-D: Development of callus; E-F: Single Cells of A. precatorius; G-H: Divisional stage of cells; I: Leaf cell derived callus in MS liquid medium with BAP; J: Internodal cell derived callus in MS liquid medium with BAP; K-L: Leaf cell derived callus in MS liquid medium with BAP+NAA combination; M-N: Internodal cell derived callus in MS liquid medium with BAP + NAA combination; O-P: Embryo formation from leaf derived callus in MS solid medium in BAP + NAA combination; Q-S: Shoot formation from mature embryos in shooting medium; T: Root formation from embryo derived shoot in rooting medium; U: Established plant in natural condition 


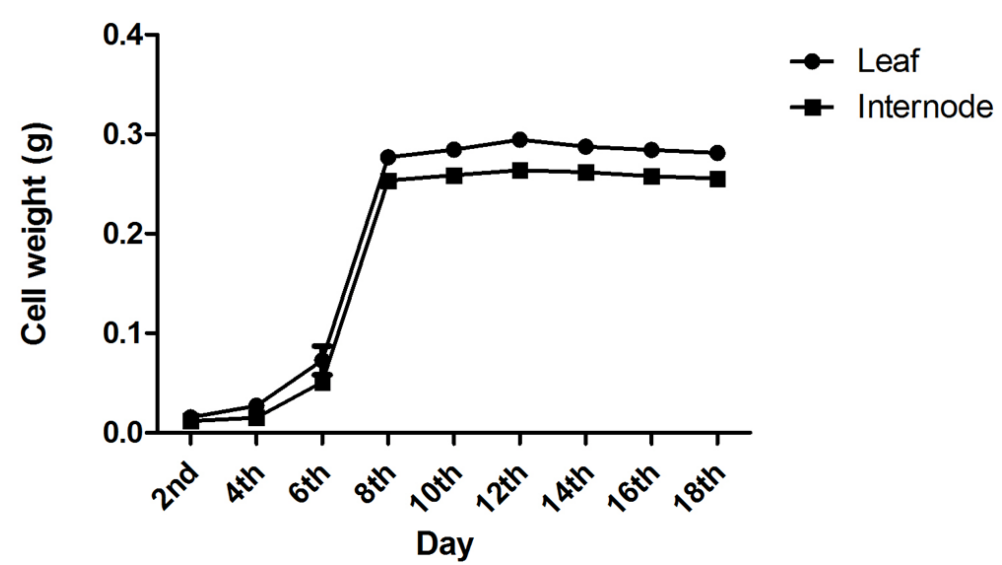

Fig. 2. Growth curve of cell growth at different time periods. There were three replications for each sample and the data was statistically significant $(\mathrm{P}<0.05)$

Embryo formation and plant regeneration through cell culture in semi solid medium

Embryo formation was observed during an 8-10 days culture. In the present experiment it was observed that embryo was formed only from creamy and friable callus and after 8-10 days. In this situation, the callus colour was turned into greenish and somatic embryos appeared. When the leaf derived callus was cultured on media supplemented with BAP, 7 embryos per callus was observed in media having $0.5 \mathrm{mg} / \mathrm{l} \mathrm{BAP}$ within $15-18$ days of culture. In case of internode derived callus, 2 embryos per callus were observed in media containing $0.5 \mathrm{mg} / \mathrm{l} \mathrm{BAP}$ and $1.0 \mathrm{mg} / \mathrm{l} \mathrm{BAP}$ within 25-27 days and 27-29 days of subculture, respectively. Callus were also cultured on MS solid media supplemented with BAP and NAA to observe somatic embryo and the results are presented in Tab. 3 .

Among all tested concentrations, $2.0 \mathrm{mg} / \mathrm{l} \mathrm{BAP}$ and 0.2 $\mathrm{mg} / \mathrm{l}$ NAA was proved to be best concentration for embryo formation. In this concentration, maximum $13 \mathrm{em}-$ bryos per callus were formed from leaf derived callus within 8-10 days of culture (Fig. 1O-1P). On the other hand maximum 10 number of embryo per culture was formed in media having $2.0 \mathrm{mg} / \mathrm{l} \mathrm{BAP}$ and $0.2 \mathrm{mg} / \mathrm{l} \mathrm{NAA}$ from internode derived callus and 18-20 days were required to induce embryo. The highest percentage of shoot induction was reported (80\%) in case of a supplementation with 2.0 $\mathrm{mg} / \mathrm{l} \mathrm{BAP}$ and $0.1 \mathrm{mg} / \mathrm{l} \mathrm{NAA}$ (Tab. 4, Fig. 1Q-1S). The average number of shoots per embryo $(6.00 \pm 0.35)$ and the average length of shoots $(4.00 \pm 0.40 \mathrm{~cm})$ were reported. The single effect of BAP was less effective for shoot regeneration than the combined effect of BAP with NAA.

The MS medium, containing $1.0 \mathrm{mg} / \mathrm{l} \mathrm{IBA}$, proved to be the more effective for rooting of regenerated shoots than that of any IBA and NAA concentration (Tab. 5, Fig. 1T). Highest, $90 \%$, having average length $(2.95 \pm 0.34$ $\mathrm{cm}$ ) of root induced at the cut end of regenerated shoots within two weeks of culture. The combined effect of IBA and NAA was less effective for root induction than the single effect of IBA. Shoots with strong and stout root system were acclimatized outside of growth chamber for one week and then transferred to earthen pots placed in natural environment containing mixture of soil and manure (1:1). Seventy five percent of plants survived in nature (Fig. 1U).

Tab. 2. Effect of BAP and NAA on callus induction from isolated single cells (each treatment consists of 200 cells). There were 3 replications for each sample

\begin{tabular}{|c|c|c|c|c|c|c|c|c|}
\hline \multirow{2}{*}{$\begin{array}{l}\text { Growth } \\
\text { regulators }(\mathrm{mg} / \mathrm{l})\end{array}$} & \multicolumn{4}{|c|}{ Leaf } & \multicolumn{4}{|c|}{ Inter node } \\
\hline & $\begin{array}{l}\text { Days to callus } \\
\text { initiation }\end{array}$ & $\begin{array}{l}\% \text { of callus } \\
\text { induction }\end{array}$ & $\begin{array}{c}\text { Color of } \\
\text { callus }\end{array}$ & $\begin{array}{l}\text { Texture } \\
\text { of callus }\end{array}$ & $\begin{array}{c}\text { Days to callus } \\
\text { initiation }\end{array}$ & $\begin{array}{l}\% \text { of callus } \\
\text { induction }\end{array}$ & $\begin{array}{c}\text { Color of } \\
\text { callus }\end{array}$ & $\begin{array}{l}\text { Texture } \\
\text { of callus }\end{array}$ \\
\hline \multicolumn{9}{|l|}{ BAP } \\
\hline 0.1 & 10 & 5.4 & Creamy & Friable & 28 & 3.2 & Creamy & Friable \\
\hline 0.2 & 9 & 6.0 & Creamy & Friable & 27 & 3.5 & Creamy & Friable \\
\hline 0.5 & 7 & 6.7 & Creamy & Friable & 25 & 4.3 & Creamy & Friable \\
\hline 1.0 & 8 & 7.3 & Creamy & Friable & 24 & 4.9 & Creamy & Friable \\
\hline \multicolumn{9}{|l|}{$\mathrm{BAP}+\mathrm{NAA}$} \\
\hline $0.5+0.1$ & 6 & 8.3 & Creamy & Friable & 22 & 5.3 & Creamy & Friable \\
\hline $0.5+0.2$ & 7 & 7.7 & Creamy & Friable & 23 & 4.7 & Creamy & Friable \\
\hline $0.5+0.5$ & 9 & 6.4 & Creamy & Friable & 26 & 3.8 & Creamy & Friable \\
\hline $1.0+0.1$ & 10 & 6.0 & White & Friable & 27 & 3.3 & White & Hard \\
\hline $1.0+0.2$ & 10 & 5.7 & White & Friable & 29 & 2.7 & White & Hard \\
\hline $2.0+0.1$ & 11 & 5.0 & White & Friable & 32 & 2.3 & White & Hard \\
\hline $2.0+0.2$ & 12 & 4.3 & White & Friable & 35 & 2.0 & White & Hard \\
\hline
\end{tabular}


Tab. 3. Formation of somatic embryo from isolated cells derived callus. There were 3 replications for each sample

\begin{tabular}{ccccc}
\hline \multirow{2}{*}{ Growth regulators } & \multicolumn{2}{c}{ Leaf callus } & \multicolumn{2}{c}{ Inter node callus } \\
\cline { 2 - 5 } & $\begin{array}{c}\text { Days of embryo } \\
\text { initiation }\end{array}$ & Number of embryo & $\begin{array}{c}\text { Days of embryo } \\
\text { initiation }\end{array}$ & Number of embryo \\
\hline BAP & $15-18$ & 7 & $25-27$ & 2 \\
0.5 & $12-15$ & 6 & $27-29$ & 2 \\
\hline 1.0 & $11-12$ & 9 & $26-28$ & 3 \\
\hline BAP+NAA & $10-12$ & 8 & $24-26$ & 4 \\
\hline $0.5+0.1$ & $12-14$ & 7 & $22-25$ & 5 \\
\hline $0.5+0.2$ & $13-15$ & 8 & $20-23$ & 6 \\
\hline $1.0+0.1$ & $9-12$ & 10 & $20-21$ & 7 \\
\hline $1.0+0.2$ & $8-10$ & 13 & $18-20$ & 10 \\
\hline $2.0+0.1$ & & & \\
\hline
\end{tabular}

Tab. 4. Effect of BAP and NAA on shoot formation from regenerated embryos. There were 3 replications for each sample

\begin{tabular}{cccc}
\hline $\begin{array}{c}\text { Growth regulators } \\
(\mathrm{mg} / \mathrm{l})\end{array}$ & $\begin{array}{c}\text { \% of embryogenesis } \\
\text { calli induced shoot }\end{array}$ & $\begin{array}{c}\text { Average No. of shoots per } \\
\text { embryonic calli (Mean } \pm \text { SE) }\end{array}$ & $\begin{array}{c}\text { Average length (cm) of shoots per embryonic } \\
\text { calli (Mean } \pm \text { SE) }\end{array}$ \\
\hline BAP & & & \\
0.5 & 20 & $3.20 \pm 0.90$ & $2.80 \pm 0.70$ \\
1.0 & 30 & $3.50 \pm 0.64$ & $3.00 \pm 0.60$ \\
1.5 & 40 & $4.00 \pm 0.50$ & $3.20 \pm 0.50$ \\
2.0 & 50 & $5.00 \pm 0.30$ & $4.00 \pm 0.40$ \\
2.5 & 45 & $4.20 \pm 0.40$ & $3.00 \pm 0.65$ \\
3.0 & 40 & $3.40 \pm 0.80$ & $2.95 \pm 0.75$ \\
\hline BAP+NAA & & & $2.90 \pm 0.80$ \\
$0.5+0.1$ & 40 & $4.20 \pm 0.94$ & $3.00 \pm 0.70$ \\
$1.0+0.1$ & 50 & $4.50 \pm 0.64$ & $3.20 \pm 0.60$ \\
$1.5+0.1$ & 60 & $5.00 \pm 0.55$ & $4.00 \pm 0.40$ \\
$2.0+0.1$ & 80 & $6.00 \pm 0.35$ & $3.25 \pm 0.65$ \\
$2.5+0.1$ & 70 & $5.20 \pm 0.50$ & $3.00 \pm 0.75$ \\
\hline $3.0+0.1$ & 40 & $4.40 \pm 0.90$ & \\
\hline
\end{tabular}

Tab. 5. Effect of NAA and IBA on root induction from regenerated embryo derived shoots. There were 3 replications for each sample

\begin{tabular}{cccc}
\hline $\begin{array}{c}\text { Growth regulators } \\
(\mathrm{mg} / \mathrm{l})\end{array}$ & \% of explant induced roots & $\begin{array}{c}\text { Average no. of roots per calli } \\
(\text { Mean } \pm \text { SE })\end{array}$ & $\begin{array}{c}\text { Average length }(\mathrm{cm}) \text { of roots } \\
(\text { Mean } \pm \text { SE })\end{array}$ \\
\hline IBA & 47 & $3.20 \pm 0.94$ & $1.62 \pm 0.20$ \\
0.1 & 60 & $3.50 \pm 0.64$ & $1.80 \pm 0.22$ \\
0.2 & 80 & $4.00 \pm 0.55$ & $2.45 \pm 0.24$ \\
0.5 & 90 & $4.50 \pm 0.35$ & $2.95 \pm 0.34$ \\
1.0 & 87 & $4.20 \pm 0.50$ & $2.87 \pm 0.44$ \\
1.5 & 67 & $3.40 \pm 0.90$ & $2.25 \pm 0.35$ \\
\hline 2.0 & 30 & & $1.60 \pm 0.20$ \\
\hline IBA NAA & 35 & $2.50 \pm 0.90$ & $1.75 \pm 0.23$ \\
\hline $0.1+0.1$ & 45 & $2.75 \pm 0.70$ & $2.40 \pm 0.25$ \\
\hline $0.2+0.1$ & 50 & $3.00 \pm 0.50$ & $2.90 \pm 0.30$ \\
\hline $0.5+0.1$ & 40 & $3.25 \pm 0.40$ & $2.80 \pm 0.40$ \\
\hline $1.0+0.1$ & 30 & $2.80 \pm 0.60$ & $2.20 \pm 0.30$ \\
\hline
\end{tabular}


92

\section{Discussion}

The highest result for callus induction was obtained (94\%) on MS media, fortified with $1.0 \mathrm{mg} / \mathrm{l} \mathrm{BAP}$ with $0.1 \mathrm{mg} / \mathrm{l}$ NAA. However, BAP with NAA were found to be more effective than the single BAP, for callus induction (Tab. 1). Callus forms frequently at the basal cut ends of internodal explants on cytokinin enriched medium in species exhibiting strong apical dominance (Preece et al., 1991).

Microscopic observation were made to characterize the individual cells isolated from the culture medium, and in regards of their shape, they may be regarded as spherical, elliptical and elongated shape (Fig. 1E, 1F). Some cells found with dense cytoplasm and part of them possessed high embryogenic potential. The embryogenic single cells and cell from the clusters are capable to divide symmetrically and asymmetrically by transverse division (Fig. 1G, $1 \mathrm{H})$, which resulted in two cell's stage proembryo. Some researchers reported asymmetrical cell division in Medicago truncatula and analyzed the formation of proembryo in the plant (Iantcheva et al., 2005). In the present investigation, a number of experiments were performed to evaluate the cell growth in culture media for the cell suspension culture on Abrus precatorius. Depending on cell growth a curve was developed to address the time range for rapid growth period. Experimental results indicated that the peak period of cell growth runs from 6-8 days and after 12 days their growth seemed to be ceased down. It means that growth period of Abrus precatorius plant runs up to 2 weeks with a peak time stands for 6-8 days. The results revealed that 2 week period appeared as typical period for the cell culture of Abrus precatorius plant and it is necessary to transfer the cell to the fresh medium after each 2 weeks of culture for its maintenance in the lab. Potential cell clones cane, selected from this condition, and cell line can be maintained for long-time periods without loss of embryogenic capacity by subculture at the end of the exponential growth phase to fresh medium (Iantcheva et al., 2006).

Under the condition of continuous shaking, in addition to cells, clump structure appeared composed of aggregated dividing cells. Cell clumps were varying sizes as observed in cell culture media. After 12-14 days, cell suspension cultures were transferred in MS liquid medium with growth regulators in Petri dishes and were placed in growth chamber under light. Fine cell suspension cultures further induced callus tissue from single cells, clusters and aggregates. Subsequent repeated divisions in multiple planes within 6-12 days resulted in the formation of globular embryos. It was reported that after 20-25 days in Medicago truncatula globular embryos were formed (Iantcheva et al., 2005). In present investigation, highest density of embryo was observed in suspension containing $0.5 \mathrm{mg} / \mathrm{l}$ BAP and $0.1 \mathrm{mg} / \mathrm{l} \mathrm{NAA}$. The embryogenic potential of this culture can be maintained for 2-3 days if the medium is refreshed every 2 weeks. Further transition to heart and torpedo stage embryos occurred within a week thereby confirming the bipolar nature of embryos. The torpedoes were thick and creamy in color. Three stages of embryos were also observed in suspension containing BAP and NAA in MS medium. Six types of somatic embryos have been also observed in Coffea arabica (Quiroz-Figueroa et al., 2002). These were globular, oblong, heart shaped, elongated, torpedo and cotyledon shaped embryos. Recallusing and induction of secondary embryogenesis were the common features observed in all suspensions.

After 2 weeks of culture, all green embryos (globular, heart shape and torpedo stage) were transferred to MS solid medium containing growth regulators for embryo proliferation. Several factors such as choice of explants, culture environment, hormonal and non-hormonal regulators act synergistically in determining proper induction, proliferation, maturation and conversion of callus into somatic embryos.

The highest percentage $(80 \%)$ of shoot induction was reported in MS media supplemented with $2.0 \mathrm{mg} / \mathrm{l} \mathrm{BAP}$ and $0.1 \mathrm{mg} / 1 \mathrm{NAA}$. For shoot proliferation, the combined effect of BAP and NAA presented to be the most effective, compared to the single effect of BAP. Similar results were previously reported in other medicinal plant species (Giri and Narasu, 2000; Patnaik and Debata, 1996; Saxena et al., 1997). The highest percentage (90\%) of root induction was reported in MS media supplemented with 1.0 $\mathrm{mg} / \mathrm{l}$ IBA. In this case, single effect of IBA was proved to be more effective for rooting of regenerated shoots than that of any concentration of IBA and NAA. The effectiveness of IBA in rooting has been reported in many medicinal plants (Chandramu et al., 2003; Martin, 2002).

For exploring cell culture, towards production of secondary metabolites, Abrus precatorius holds several special advantages. The plant used to produce abundant callus from the easily available explants like leaf and internode in MS medium. Large quantity of embryogenic callus can be obtained within 10-12 days and easily available callus is the potential source of cell culture. Within 6-8 days cells are produced in its peak level of production. The main objective was to produce the secondary metabolites i.e. abrin from this cell culture. The protocol for cell culture from Abrus precatorius has been well established under the present investigation but it did not lead to the possibility to extract the abrin from its cell culture due to necessary lab facilities. Further research endeavor is needed to extract the abrin from cell cultures and to use other enhancing materials (elicitation and bioreactor) to intensify the production capacity of the culture.

\section{References}

Balandrin MJ, Klocke JA (1988). Medicinal, aromatic and industrial materials from plants, 1-36 p. In: Bajaj YPS (Ed.). Biotechnology in Agriculture and Forestry. Medicinal and 
Aromatic Plant, vol. 4. Springer-Verlag, Berlin, Heidelberg.

Chandramu C, Rao DM, Reddy DV (2003). High frequency induction of multiple shoot from nodal explants of Vitex nigundu L. using sodium sulphate. J Plant Biotechnol 5(2):107-113.

Cheetham PSJ (1995). Biotransformations: new routes to food ingredients. Chemical Industry, 265-268 p.

Dicosmo F, Misawa M (1995). Plant cell and tissue culture: Alternatives for metabolite production. Biotechnol Adv 13(3):425-453.

Dixon RA, Sharma SB, Xie D (2005). Proanthocyanidins-a final frontier in flavonoid research? New Phytol 165:9-28.

Elio GWM, Schijlen CHR, Ric de V., Arjen J, Van T., Arnaud GB (2004). Modification of flavonoid biosynthesis in crop plants. Phytochem 65:2631-2648.

Facchini PJ, Bird DA, St.-Pierre B (2004). Can Arabidopsis make complex alkaloid? Trends Plant Sci 9:116-122

Giri A, Narasu ML (2000). Transgenic hairy roots: recent trends and applications. Biotechnol Adv 18:1-22.

Goossens A, Hakkinen S, Laakso I, Seppanen-Laakso T, Biondi S, De sutter V, Lammertyn F, Nuutila A, Soderlund H, Zabeau M (2003). A functional genomics approach toward the understanding of secondary metabolism in plant cells. PNAS 100:8595-8600.

Grotewold E (2004). The challenges of moving chemicals wethen and out of cells: insights into the transport of plant natural products. Planta 219:906-909.

Hansen G, Wright MS (1999). Recent advances in the transformation of plants. Trends Plant Sci 4:226-231.

Hossain MJ, Rahman M, Bari MA (2007). Establishment of cell suspension culture and plant regenetation of Brinjal (Solanum melongena L.). J Plant Sci 2(4):407-415.

Iantcheva A, Vlahova M, Atanassov A, Duque AS, Araujo S, Dos Santos DF, Fevereiro P (2006). Cell suspension cultures. Medicago truncatula handbook. Agro Bio Institute, 1164 Sofia, Bul. Dragan Tzankov 8, Bulgaria.

Iantcheva A, Slavov S, Prinsen E, Vlahova M, Van Onckelen $\mathrm{H}$, Atanassov A (2005). Embryo induction and generation from root explants of Medicago truncatula after osmotic pretreatment. Plant Cell Tissue Organ Cult 81:37-43.

Jung GY, Stephanopoulos G (2004). A functional protein chip for pathway optimization and in vitro metabolic engineering. Science 304:428-431.

Krings U, Berger RG (1998). Biotechnological production of flavours and fragrances. Appl. Microb. Biotechnol 49 (1):18.
Martin KP (2002). Rapid propagation of Holostema adakodien Schult. A rare medicinal plant, through axilary bud multiplication and indirect organogenesis. Plant Cell Rep 21:112-117.

Murashige T, Skoog F (1962). A revised medium for rapid growth and bioassays with tobacco tissue cultures. Physiol Plant 15:473-497.

Patnaik J, Debata BK (1996). Micropropagation of Hemidesmus indicus (L.) R. Br. Through axillary bud culture. Plant Cell Rep 15:427-430.

Phillipson JD (1990). Plants as source of valuable products, 1-21 p. In: Charlwood BV, Rhodes MJC (Eds.). Secondary Products from Plant Tissue Culture. Oxford: Clarendon Press.

Preece JE, Hutterman CA, Ashby WC, Roth PL (1991). Micro and cutting propagation of silver maple. 1 . Results with adult and juvenile propagules. J Am Soc Horticult Sci 116:142148.

Quiroz-Figueroa FR, Fuentes-Cerda CFJ, Rojas-Herrera R, Loyola-Vargas M (2002). Histological studies on the development stages and differentiation of two different somatic embryogenesis systems of Coffea Arabica. Plant Cell Rep 20(12):1141-1149.

Ralley L, Enfissi EMA, Misawa N, Schuch W, Bramley PM, Fraser PD (2004). Metabolic engineering of ketocarotenoid formation in higher plants. Plant J 39:477-486

Ramachandra RS, Ravishankar GA (2002). Plant cell cultures: Chemical factories of secondary metabolites. Biotechnol Adv 20:101-153.

Ravishankar GA, Rao SR (2000). Biotechnological production of phyto-pharmaceuticals. The J Biochem, Molec Biol Biophysics 4:73-102.

Sajc L, Grubisic D, Vunjak-Novakovic G (2000). Bioreactors for plant engineering: an outlook for further research. Biochem Engineer J 4:89-99.

Saxena C, Rout GR, Das P (1997). Micropropagation of Psoralea corylifolia L. J Med Arom Plant Sci 20:15-18.

Vanisree M, Hsin-Sheng T (2004). Plant cell cultures-An alternative and efficint source for the production of biological important secondary metabolites. Internat J Engineer Appl Sci 2(1):29-48.

Winkel BSJ (2004). Metabolic channeling in plants. Ann Review Plant Biol 55:85-107.

Zhang JZ (2003) Overexpression analysis of plant transcription factors. Current Opin Plant Biol 6:430-440. 